\title{
MODIFIKASI HUKUM KEWENANGAN INSPEKTORAT DAERAH KABUPATEN/KOTA DALAM MENCEGAH TERJADINYA TINDAK PIDANA KORUPSI DI PEMERINTAH DAERAH KABUPATEN/KOTA
}

\author{
Andry Lauda, Pengawas Pemerintah Muda di Inspektorat Kota Batu, \\ E-mail: lauda_oniestudio@yahoo.com
}

\begin{abstract}
Abstrak
Penelitian ini bertujuan untuk mengetahui bentuk modifikasi hukum kewenangan inspektorat daerah kabupaten/kota dalam mencegah terjadinya tindak pidana korupsi di pemerintah daerah kabupaten/kota. Metode penelitian yang digunakan adalah penelitian penelitian hukum normatif. Hasil penelitian menunjukkan bahwa kewenangan yang dimiliki Inspektorat Daerah Kabupaten/Kota sebagaimana diatur dalam beberapa peraturan perundangundangan mendesak untuk dimodifikasi untuk memperkuat kewenangan Inspektorat Kabupaten/Kota dalam mencegah terjadinya tindak pidana korupsi di Pemerintah Daerah Kabupaten/Kota. Modifikasi dimaksud dilakukan dalam bentuk revisi/perubahan peraturan perundang-undangan, di mana saat ini kedudukan Inspektorat Kabupaten/Kota masih sejajar dengan Organisasi Perangkat Daerah, ke depan menjadi sejajar dengan Sekretaris Daerah. Modifikasi kedua dilakukan dalam bentuk reposisi Peran/Tugas Inspektorat Daerah Kabupaten/Kota dengan cara mendorong terwujudnya Good Governance dan Clean Government, Menumbuh kembangkan Sinergi Pengawasan, Mendukung Upaya Pemberantasan KKN, Mengoptimalkan Peningkatan Penerimaan Negara, Berperan dalam Pelaksanaan Otonomi Daerah. Sedangkan modifikasi ketiga yang dapat dilakukan dengan cara Pengembangan Kelembagaan melalui pengembangan struktur, Prosedur Kerja, dan Sumber Daya Manusia.
\end{abstract}

Kata Kunci : Modifikasi Hukum, Kewenangan, Inspektorat Kabupaten/Kota

\section{PENDAHULUAN}

\section{Latar Belakang}

Pemberian otonomi yang seluas-luasnya kepada Daerah diarahkan untuk mempercepat terwujudnya kesejahteraan masyarakat melalui peningkatan pelayanan, pemberdayaan, dan peran serta masyarakat. Di samping itu melalui otonomi luas, dalam lingkungan strategis globalisasi, Daerah diharapkan mampu meningkatkan daya saing dengan memperhatikan prinsip demokrasi, pemerataan, keadilan, keistimewaan dan kekhususan serta potensi dan keanekaragaman Daerah dalam sistem Negara Kesatuan Republik Indonesia. Pemberian otonomi yang seluas-seluasnya kepada Daerah dilaksanakan berdasarkan prinsip negara kesatuan. Dalam negara kesatuan kedaulatan hanya ada pada pemerintahan negara atau pemerintahan nasional dan tidak ada kedaulatan pada Daerah. Oleh karena itu, seluas apa pun otonomi yang diberikan kepada Daerah, tanggung jawab akhir penyelenggaraan Pemerintahan Daerah akan tetap ada ditangan Pemerintah Pusat. Untuk itu Pemerintahan Daerah pada Negara kesatuan merupakan satu kesatuan dengan Pemerintahan Nasional. Sejalan dengan itu, kebijakan yang dibuat dan dilaksanakan oleh Daerah merupakan bagian integral dari kebijakan nasional. Pembedanya adalah terletak pada bagaimana memanfaatkan kearifan, potensi, inovasi, daya saing, dan kreativitas Daerah untuk mencapai tujuan nasional tersebut di tingkat lokal yang pada gilirannya akan mendukung pencapaian tujuan nasional secara keseluruhan.

Pada hakikatnya Otonomi Daerah diberikan kepada rakyat sebagai satu kesatuan masyarakat hukum yang diberi kewenangan untuk mengatur dan mengurus sendiri 
Urusan Pemerintahan yang diberikan oleh Pemerintah Pusat kepada Daerah dan dalam pelaksanaannya dilakukan oleh kepala daerah dan DPRD dengan dibantu oleh Perangkat Daerah. Mengingat kondisi geografis yang sangat luas, maka untuk efektifitas dan efisiensi pembinaan dan pengawasan atas penyelenggaraan Urusan Pemerintahan yang menjadi kewenangan Daerah kabupaten/kota, Presiden sebagai penanggung jawab akhir pemerintahan secara keseluruhan melimpahkan kewenangannya kepada gubernur untuk bertindak atas nama Pemerintah Pusat untuk melakukan pembinaan dan pengawasan kepada Daerah kabupaten/kota.

Kewenangan yang luas membutuhkan pengawasan yang optimal, karena tanpa pengawasan terbuka peluang terjadinya penyimpangan dan penyalahgunaan kewenangan, sehingga akan mengakibatkan kerugian keuangan negara, dan tidak terwujudnya kesejahteraan masyarakat. Pengawasan pada hakekatnya adalah mencegah sedini mungkin terjadinya penyimpangan, pemborosan, penyelewengan, hambatan, kesalahan, kegagalan dalam pencapaian tujuan dan pelaksanaan tugas-tugas organisasi. Pengawasan adalah proses pengamatan dari pada pelaksanaan seluruh kegiatan organisasi untuk menjamin agar semua pekerjaan yang dilakukan berjalan sesuai rencana yang telah ditentukan sebelumnya.

Pengawasan yang efektif diharapkan dapat meningkatkan pendayagunaan aparatur negara dalam melaksanakan tugas-tugas umum pemerintahan dan pembangunan menuju terwujudnya pemerintahan yang baik dan bersih (good and clean governance). Pengawasan sebagaimana dimaksud dilaksanakan oleh APIP sesuai dengan fungsi dan kewenangannya. Pembinaan dan pengawasan kepala daerah terhadap Perangkat Daerah dilaksanakan oleh bupati/walikota untuk daerah kabupaten/kota dengan dibantu oleh Inspektorat Daerah Kabupaten/Kota. Pembinaan dan pengawasan dilaksanakan dalam bentuk audit, reviu, monitoring, evaluasi, pemantauan, dan bimbingan teknis serta bentuk pembinaan dan pengawasan lainnya.

Dasar hukum yang dapat dijadikan acuan dalam pelaksanaan pengawasan adalah mengacu pada Undang-Undang Nomor 23 Tahun 2014 tentang pemerintahan daerah yang diperkuat oleh Peraturan Pemerintah Nomor 12 Tahun 2017 Tentang Pembinaan dan Pengawasan Penyelenggaraan Pemerintahan Daerah dan Peraturan Menteri Dalam Negeri Nomor 64 Tahun 2007 tentang pedoman teknis organisasi dan tata kerja Inspektorat Provinsi dan Kabupaten/Kota.

Secara filosofis, problematika pengawasan Internal di Indonesia terletak pada fundamen pemahaman mengenai pengawasan internal. Salah satu pokok-pokok pikiran Lawrence B. Sawyer dalam artikelnya yang terkenal, yaitu "An internal Audit philosophy"(1995) menyebutkan bahwa fungsi audit internal harus didasarkan pada mandat/kewenangan yang kuat dan jelas.

Fungsi pengawasan internal akan terlaksana dengan baik jika memiliki kewenangan/mandat dan landasan hukum yang jelas dan kuat serta mendapatkan dukungan dari pimpinan tertinggi dalam organisasi. Jika yang terjadi sebaliknya, maka sebagus apapun sumber daya manusia, sarana prasarana, dana, dan metode kerja yang dimiliki oleh organisasi pengawas internal, hal itu hampir pasti tidak akan mampu 
mengubah impian stakeholders menjadi lebih baik dibandingkan dengan kondisi sebelumnya. ${ }^{1}$

Selain problematika filosofis, secara teoritis terkait dengan tugas dan peran pengawasan internal yang dilakukan oleh Inspektorat Kabupaten/Kota dalam penyelenggaraan pemerintahan yang bersih dan bebas dari korupsi, kolusi dan nepotisme sebagaimana diamanatkan dalam Undang-Undang nomor 31 tahun 1999 sebagaimana telah diubah dengan Undang-Undang Nomor 20 Tahun 2001 tentang pemberantasan tindak pidana korupsi juga menjadi problematika tersendiri. Inspektorat Kabupaten/Kota yang seharusnya juga memainkan peran penting dalam hal pemberantasan tindak pidana korupsi, kolusi dan nepotisme (KKN) dapat dikatakan belum melaksanakan tugas dan perannya.

Selain problematika filosofis, dan teoritis, permasalahan secara yuridis terkait dengan konsep independensi pengawas internal atau bisa disebut sebagai konsep independensi Inspektorat Kabupaten/Kota juga menjadi problematika dalam mewujudkan pelaksanaan tata kelola pemerintahan yang baik, dan percepatan menuju good governance, clean government, dan pelayanan publik, khususnya dalam mencegah dan memberantas korupsi. Independensi menjadi landasan atau dasar utama dalam efektifitas pengawasan dari Inspektorat Daerah Kabupaten/Kota dalam melakukan fungsi pengawasan terhadap penyelenggaraan pemerintahan. Saat ini independensi dari Inspektorat Daerah Kabupaten/Kota dalam melakukan fungsi pengawasan dan pemeriksaan belum nampak dan belum berjalan secara efektif, hal ini disebabkan karena kedudukan dari Inspektorat Daerah Kabupaten/Kota masih dibawah tanggung jawab dari Kepala Daerah.

Problematika secara filosofis, teoritis dan yuridis sehubungan dengan Inspektorat Kabupaten/Kota telah diungkap di atas, berikutnya adalah problematika empiris yang dihadapi inspektorat Kabupaten/Kota melalui Aparat Pengawas Internal Pemerintah (APIP) dalam menjalankan tugasnya. Dalam hal ini akan dilihat bagaimana sebenarnya kondisi nyata Inspektorat Kabupaten/Kota dalam menjalankan fungsi pengawasan.

Dalam beberapa bulan terakhir, kita ketahui bersama Komisi Pemberantasan Korupsi ( KPK) semakin gencar melakukan operasi tangkap tangan (OTT) di sejumlah daerah. Sepanjang 2017 ini, dari berbagai operasi tangkap tangan yang dilakukan KPK, ada 5 kepala daerah yang terjaring atas dugaan tindak pidana korupsi yaitu : Gubernur Bengkulu Ridwan Mukti, Bupati Pamekasan Achmad Syafii, Wali Kota Tegal Siti Masitha, Bupati Batubara OK Arya Zulkarnaen, dan Wali Kota Batu Eddy Rumpoko. ${ }^{2}$

Masih banyaknya kepala daerah yang tertangkap melakukan korupsi telah menimbulkan pertanyaan akan peran Inspektorat Daerah Kabupaten/Kota dalam melakukan pengawasan di daerah. Berdasarkan informasi dari KPK, penangkapan kepala daerah tidak ada yang didasarkan atas laporan inspektorat di daerah, namun atas pengaduan masyarakat. ${ }^{3}$ Padahal, tugas Inspektorat Daerah Kabupaten/Kota adalah

\footnotetext{
1 Wakhyudi, Ak., M.B.A, et al., Filosofi Auditing , (Jakarta, 2007), hlm. 8.

2 Umar Sholahudin, Maraknya Korupsi Pejabat Daerah, https://www.jawapos.com/read/2017/10/08/161493/ maraknya-korupsi-pejabat-daerah

${ }^{3}$ Riris Katharina, Memperkuat Peran Inspektorat Daerah Dalam Pemberantasan Korupsi, majalah info singkat pemerintahan dalam negeri vol IX no. 18/II/Puslit/September/2017
} 
melakukan pengawasan terhadap seluruh kegiatan dalam rangka penyelenggaraan tugas dan fungsi satuan kerja perangkat daerah yang didanai dengan Anggaran Pendapatan dan Belanja Daerah (APBD). Artinya, apabila inspektorat bekerja dengan baik, dapat dipastikan tingkat korupsi di daerah akan menurun.

Sesungguhnya Inspektorat Daerah Kabupaten/Kota telah diberikan peran yang cukup signifikan dan pengaturan yang lebih baik. Peran Inspektorat Daerah Kabupaten/Kota yang semula hanya bersifat represif, telah berkembang menjadi preventif. Inspektorat Daerah Kabupaten/Kota juga diberikan peran sebagai konsultan antara lain dengan melakukan quality assurance bagi Satuan Kerja Perangkat Daerah (SKPD) di daerahnya. Dengan demikian, setiap SKPD dapat berkonsultasi dengan Inspektorat Daerah Kabupaten/Kota terkait penggunaan anggaran negara agar tidak menimbulkan praktik pelanggaran hukum. Namun, peningkatan peran dan pengaturan tersebut dalam praktiknya belum secara signifikan menurunkan angka korupsi di daerah.

Mencermati beberapa permasalahan diatas terkait dengan kewenangan dan nilai strategis Inspektorat Kabupaten/Kota dalam pencegahan dan pemberantasan korupsi, maka memang perlu dilakukan penataan ulang terkait kewenangan Inspektorat Kabupaten/Kota sebagai salah satu pintu awal untuk mencegah terjadinya tindak pidana korupsi di lingkungan pemerintah daerah, karena kenyataan yang terjadi saat ini Inspektorat Kabupaten/Kota belum dapat menjalankan kewajibannya dalam mencegah dan memberantas tindak pidana korupsi di masing-masing instansinya secara maksimal.

\section{Rumusan Masalah}

1. Bagaimana bentuk kewenangan yang dimiliki oleh Inspektorat Daerah Kabupaten/Kota dalam hal pengawasan khususnya dalam mencegah terjadinya tindak pidana korupsi?

2. Mengapa kewenangan yang dimiliki oleh Inspektorat Daerah Kabupaten/Kota dalam hal pengawasan saat ini masih belum mampu mencegah terjadinya tindak pidana korupsi di Pemerintah Daerah Kabupaten/Kota?

3. Bagaimana modifikasi hukum kewenangan Inspektorat Kabupaten/Kota dalam mencegah terjadinya tindak pidana korupsi di Pemerintah Daerah Kabupaten/Kota?

\section{METODE PENELITIAN}

Metode merupakan suatu unsur yang mutlak harus ada dalam penelitian dan pengembangan ilmu pengetahuan. ${ }^{4}$ Penelitian ini tergolong penelitian hukum normatif yang bersifat deskriptif-analisis dengan memperhatikan peraturan perundang-undangan yang mengatur tentang modifikasi hukum kewenangan Inspektorat Daerah Kabupaten/Kota dalam mencegah terjadinya tindak pidana korupsi. Menurut Soerjono Soekanto,5 "penelitian hukum normatif mencakup: (1) penelitian terhadap asas-asas hukum, (2) penelitian terhadap sistematika hukum, (3) penelitian terhadap taraf sinkronisasi hukum, (4) penelitian terhadap sejarah hukum, dan (5) penelitian perbandingan hukum.

\footnotetext{
4 Soerjono Soekanto, Pengantar Penelitian Hukum, (Cetakan Ketiga), ( Jakarta, 1986), hlm. 7.

${ }^{5} \mathrm{Ibid}, \mathrm{hlm} .51$.
} 
Penelitian hukum ini memandang hukum dalam arti proses pemerintah (lembaga hukum-legal institution) ${ }^{6}$. Penelitian hukum ini juga tergolong dalam penelitian hukum interdisipliner karena penelitian hukum ini untuk menemukan suatu kebijakan (policy) pemerintah yang baru.

Dalam penelitian ini, pendekatan penelitiannya menggunakan pendekatan undangundang (statute approach), dan pendekatan konseptual (conceptual approach). Pendekatan undang-undang (statute approach) dilakukan dengan menelaah semua undang-undang dan regulasi yang bersangkut paut dengan isu hukum yang sedang ditangani. ${ }^{7}$ Dalam metode pendekatan undang-undang peneliti perlu memahami hierarki, dan asas-asas dalam peraturan perundang-undangan. ${ }^{8}$ Pendekatan undang-undang dalam penelitian ini bertujuan untuk mengkaji eksistensi dan implikasi dari berbagai macam peraturan perundang-undangan yang mana merupakan manifestasi dari kewenangan Inspektorat Kabupaten/Kota dalam mencegah terjadinya tindak pidana korupsi di Pemerintah Daerah.

Sedangkan yang berikutnya adalah pendekatan konseptual. Pendekatan konseptual beranjak dari pandangan-pandangan dan doktrin-doktrin yang berkembang di dalam ilmu hukum. Dengan mempelajari pandangan-pandangan dan doktrin-doktrin di dalam ilmu hukum, peneliti akan menemukan ide-ide yang melahirkan pengertian-pengertian hukum, konsep-konsep hukum dan asas-asas hukum yang relevan dengan isu yang dihadapi. Pemahaman akan pandangan-pandangan dan doktrin-doktrin tersebut merupakan sandaran bagi peneliti dalam membangun suatu argumentasi hukum dalam memecahkan isu yang dihadapi. ${ }^{9}$ Dengan demikian, melalui pendekatan konseptual, bisa diperoleh jawaban mengenai modifikasi hukum kewenangan Inspektorat Daerah Kabupaten/Kota dalam mencegah terjadinya tindak pidana korupsi di pemerintah daerah Kabupaten/Kota.

Menurut Soerjono Soekanto, 10 "... pada penelitian hukum normatif yang diteliti hanya bahan pustaka atau data sekunder, yang mungkin mencakup bahan hukum primer, sekunder dan tertier". Bahan hukum primer yaitu bahan-bahan hukum yang mengikat; bahan hukum sekunder adalah bahan hukum yang memberikan penjelasan mengenai bahan hukum primer, seperti misalnya, rancangan undang-undang, hasil-hasil penelitian, hasil karya dari kalangan hukum, dan seterusnya; serta bahan hukum tertier adalah bahan yang memberikan petunjuk maupun penjelasan terhadap bahan hukum primer dan sekunder, misalnya kamus, ensiklopedia, indeks kumulatif, dan seterusnya. ${ }^{11}$

\footnotetext{
${ }^{6}$ Lihat C.F.G. Sunaryati Hartono, 2006, Penelitian Hukum di Indonesia Pada AKhir Abad ke-20, Penerbit Alumni, Bandung, hlm. 117. Lihat juga pendapat dari Satjipto Rahardjo mengenai pilihan penggunaan metode penelitian hukum dalam Johnny Ibrahim, 2008, Teori \& Metodologi Penelitian Hukum Normatif, Bayumedia, Malang, hlm. 37-38. Beliau menjelaskan jika melihat hukum sebagai suatu system yang abstrak, maka perhatiannya akan terpusat pada hukum sebagai suatu lembaga yang benar-benar otonom dan konsekuensinya adalah penggunaan metode normatif atau juga disebut normatif analitis.

7 Ibid., hlm.93.

8 Ibid., hlm. 96.

${ }^{9}$ Ibid., hlm 95.

${ }^{10}$ Soerjono Soekanto, Op. Cit., hlm. 52.

11 Ibid.
} 
Tahapan penelitian yang digunakan dalam penelitian ini adalah penelitian kepustakaan (studi pustaka) dan studi dokumen yang didukung dengan tahapan penelitian lapangan (field research).

Penelitian kepustakaan dan studi dokumen yang bertujuan untuk mencari bahan hukum dapat diuraikan sebagai berikut:

1. Bahan Hukum Primer, Meliputi Undang-Undang Dan Peraturan Pelaksana UndangUndang Yang Berkaitan Dengan Permasalahan Hukum Yang Diteliti, Diantaranya :

a. Undang-Undang Nomor 31 Tahun 1999 jo Undang-Undang Nomor 20 Tahun 2001 tentang Pemberantasan Tindak Pidana Korupsi

b. Undang-Undang Republik Indonesia Nomor 23 Tahun 2014 Tentang Pemerintahan Daerah

c. Peraturan Pemerintah Republik Indonesia Nomor 12 Tahun 2017 Tentang Pembinaan Dan Pengawasan Penyelenggaraan Pemerintahan Daerah,

d. Peraturan Pemerintah Republik Indonesia Nomor 18 Tahun 2016 Tentang Perangkat Daerah,

e. Peraturan Menteri Dalam Negeri Nomor 64 Tahun 2007 Tentang Pedoman Teknis Organisasi Dan Tata Kerja Inspektorat Provinsi Dan Kabupaten/Kota,

f. Peraturan Menteri Dalam Negeri Nomor 8 Tahun 2009 Tentang Perubahan Atas Peraturan Menteri Dalam Negeri Nomor 23 Tahun 2007 Tentang Pedoman Tata Cara Pengawasan Atas Penyelenggaraan Pemerintahan Daerah,

2. Bahan hukum sekunder, meliputi dokumen hukum, laporan hukum, catatan hukum, teori hukum, asas hukum, doktrin hukum, jurnal hukum, naskah akademik peraturan perundang-undangan dan informasi hukum yang relevan dengan permasalahan hukum dalam penelitian ini.

3. Bahan hukum tertier, meliputi istilah-istilah yang diambil dari kamus hukum dan ensiklopedia hukum serta bibliografi yang ada relevansinya dengan permasalahan yang diteliti.

Dalam analisis bahan hukum pada dasarnya tergantung pada jenis bahan hukum itu sendiri. Untuk penelitian hukum normatif yang hanya mengenal data sekunder saja yang mana hanya terdiri dari bahan hukum primer, bahan hukum sekunder, dan bahan hukum tersier, maka dalam menganalisis bahan hukum tersebut tidak bisa melepaskan diri dari berbagai penafsiran yang dikenal dalam ilmu hukum. ${ }^{12}$ Interpretasi atau penafsiran merupakan salah satu metode penemuan hukum yang memberi penjelasan secara gamblang mengenai teks Undang-undang agar ruang lingkup kaedah dapat ditetapkan sehubungan dengan peristiwa tertentu. ${ }^{13}$ Interpretasi atau penafsiran yang dikenal dalam ilmu hukum antara lain meliputi interpretasi autentik, interpretasi gramatikal, interpretasi sistematis, interpretasi teleologi atau sosiologi, interpretasi historis, interpretasi komparatif dan interpretasi futuristis.

\footnotetext{
12 Amirudin dan Zainal Asikin, Pengantar Metode Penelitian Hukum, (Jakarta, 2004), hlm. 163.

13 Sudikno Mertokusumo, Mengenal Hukum : Suatu Pengantar, (Yogyakarta, 2004), hlm 169.
} 


\section{KEWENANGAN YANG DIMILIKI OLEH INSPEKTORAT DAERAH KABUPATEN/KOTA DALAM HAL PENGAWASAN KHUSUSNYA DALAM MENCEGAH TERJADINYA TINDAK PIDANA KORUPSI}

\section{Gambaran Umum tentang Kewenangan}

Kewenangan yang selanjutnya disebut sebagai authority atau bevoegheid, diartikan sebagai hak untuk bertindak dan mengeluarkan perintah dengan kekuasaan yang dimiliki oleh pejabat umum atau lembaga negara. Kewenangan memiliki keabsahan ketika kewenangan tersebut diperoleh berdasarkan hukum. Tiada kewenangan dianggap sah secara hukum ketika kewenangan tersebut tidak berasal dari hukum atau peraturan perundang-undangan, yang selanjutnya prinsip tersebut dikenal dengan Asas Legalitas (Legalitet Beginsel).

Asas legalitas (legaliteitsbeginsel atau het beginsel van wetmatigheis van bestuur) merupakan salah satu prinsip utama yang dijadikan dasar penyelenggaraan pemerintahan negara, khususnya negara hukum. Asas legalitas ini di dalam hukum administrasi mengandung makna, pemerintah tunduk kepada undang-undang, dan semua ketentuan yang mengikat warga negara harus di dasarkan pada undang-undang. Oleh karena itu, asas legalitas merupakan dasar utama dalam kewenangan pemerintah. ${ }^{14}$

Inspektorat Daerah Kabupaten/Kota pada hakikatnya mendorong terwujudnya Good Governance dan Clean Government dengan melakukan pendekatan pencegahan dini (early warning) terhadap kemungkinan terjadinya kesalahan, tindakan penyimpangan, penyalahgunaan wewenang dan tindakan $\mathrm{KKN}$, sehingga dalam menjalankan tugas Inspektorat Daerah Kabupaten/Kota tidak hanya berfungsi sebagai watch dog tetapi lebih mengedepankan fungsi consultant dan quality assurer. Sejalan dengan itu maka Inspektorat Inspektorat Daerah Kabupaten/Kota dituntut untuk selalu berada di bagian terdepan dalam rangka mengawal pelaksanaan penyelenggaraan Pemerintahan Daerah.

\section{Dasar Hukum Kewenangan Inspektorat Kabupaten/Kota}

Dasar hukum kewenangan dari inspektorat daerah kabupaten/kota di Indonesia, yaitu :

1. Undang-Undang Nomor 23 Tahun 2014 tentang Pemerintahan Daerah

2. Peraturan Pemerintah Republik Indonesia Nomor 60 Tahun 2008 tentang Sistem Pengendalian Internal Pemerintah

3. Peraturan Pemerintah Republik Indonesia Nomor 18 Tahun 2016 Tentang Perangkat Daerah

4. Peraturan Pemerintah Republik Indonesia Nomor 12 Tahun 2017 tentang Pembinaan Dan Pengawasan Penyelenggaraan Pemerintahan Daerah

5. Peraturan Presiden Nomor 54 Tahun 2010 tentang Pengadaan Barang/Jasa Pemerintah

6. Peraturan Menteri Dalam Negeri Nomor 64 Tahun 2007 tentang Pedoman Teknis Organisasi Dan Tata Kerja Inspektorat Provinsi Dan Kabupaten/Kota.

Berdasarkan perundang-undangan diatas, maka kewenangan Inspektorat Kabupaten/Kota adalah membina dan mengawasi pelaksanaan Urusan Pemerintahan yang menjadi kewenangan Daerah dan Tugas Pembantuan oleh Perangkat Daerah. Pembinaan dan pengawasan sebagaimana dimaksud meliputi: pelaksanaan urusan pemerintahan yang menjadi kewenangan daerah; pelaksanaan tugas pembantuan yang

${ }^{14}$ Sadijono, op.cit. Hlm.55. 
bersumber dari anggaran pendapatan dan belanja daerah; ketaatan terhadap ketentuan peraturan perundang-undangan termasuk ketaatan pelaksanaan norma, standar, prosedur, dan kriteria yang ditetapkan oleh Pemerintah Pusat dalam tahap perencanaan, penganggaran, pengorganisasian, pelaksanaan, pelaporan, evaluasi, dan pertanggungjawaban atas pelaksanaan urusan pemerintahan yang menjadi kewenangan daerah; dan akuntabilitas pengelolaan keuangan daerah yang bersumber dari anggaran pendapatan dan belanja daerah. Pembinaan dan pengawasan sebagaimana dimaksud dilaksanakan berdasarkan prinsip profesional; independen; objektif; tidak tumpang tindih antar-APIP; dan berorientasi pada perbaikan dan peringatan dini yang meliputi:

a. pemeriksaan dan penilaian atas manfaat dan keberhasilan kebijakan serta pelaksanaan program dan kegiatan;

b. pemeriksaan secara berkala atau sewaktu-waktu maupun pemeriksaan terpadu;

c. reviu terhadap dokumen atau laporan secara bcrkala atau sewaktu-waktu dari Perangkat Daerah;

d. pengusutan atas kebenaran laporan mengenai adanya indikasi terjadinya penyimpangan, korupsi, kolusi, dan nepotisme; dan

e. monitoring dan evaluasi terhadap program dan kegiatan Perangkat Daerah.

\section{Kedudukan Hirarkis Ketatanegaraan dan Pertanggungjawaban Kewenangan}

Konsep kedudukan hirarkis ketatanegaraan dan pola pertanggungjawaban kewenangan pengawasan internal Inspektorat dapat dianalisis dengan bagaimana mekanisme pengelolaan keuangan negara dari pusat hingga daerah, meliputi kedudukan pejabat pengelola anggaran negara dan lembaga pengawas internal yang dapat digambarkan dalam bagan berikut:

Bagan Kedudukan Hirarkis Inspektorat Kabupaten/Kota

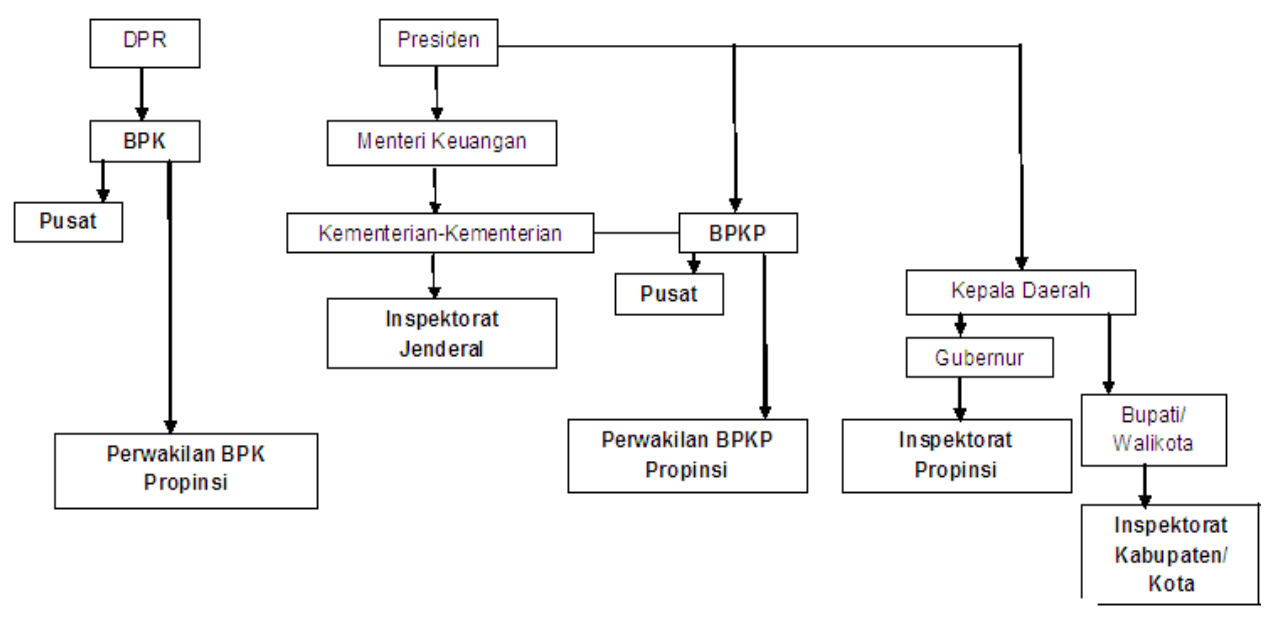

\section{Objek Pengawasan}

Inspektorat Kabupaten/Kota pada hakikatnya mengawasi badan/institusi yang terdapat di masing-masing Kabupaten/Kota yang dalam pelaksanaan kinerjanya menggunakan dana desentralisasi, dana dekonsentrasi dan dana tugas pembantuan. Dana Desentralisasi atau perimbangan adalah dana yang bersumber dari pendapatan APBN yang dialokasikan kepada daerah untuk mendanai kebutuhan dalam rangka pelaksanaan Desentralisasi. Dana Dekonsentrasi adalah dana yang berasal dari APBN yang 
dilaksanakan oleh Bupati/Walikota sebagai wakil pemerintah yang mencakup semua penerimaan dan pengeluaran dalam rangka pelaksanaan dekonsentrasi, tidak termasuk dana yang dialokasikan untuk instansi vertikal pusat di daerah. Dana Tugas Pembantuan adalah dana yang berasal dari APBN yang dilaksanakan oleh daerah yang mencakup semua penerimaan dan pengeluaran dalam rangka pelaksanaan Tugas Pembantuan.

\section{PENYEBAB TIDAK EFEKTIFNYA KEWENANGAN YANG DIMILIKI OLEH INSPEKTORAT DAERAH KABUPATEN/KOTA DALAM MENCEGAH TERJADINYA TINDAK PIDANA KORUPSI DI PEMERINTAH DAERAH KABUPATEN/KOTA.}

\section{Peran Inspektorat Daerah Kabupaten/Kota Dalam Pengawasan Instansi Pemerintah}

Aparat Pengawasan Intern Pemerintah (APIP) dalam hal ini Inspektorat Daerah Kabupaten/Kota adalah Instansi Pemerintah yang mempunyai tugas pokok dan fungsi melakukan pengawasan, dan bertanggung jawab kepada Bupati/Walikota. Sesuai dengan tugas dan kewenangannya, maka Inspektorat Daerah Kabupaten/Kota melakukan tugas pengawasan internal pemerintah. Peraturan Menteri Pendayagunaan Aparatur Negara dan Reformasi Birokrasi Nomor 19 tahun 2009 tentang Pedoman Kendali Mutu APIP, mendefinisikan Pengawasan intern sebagai seluruh proses kegiatan audit, reviu, evaluasi, pemantauan, dan kegiatan pengawasan lain terhadap penyelenggaraan tugas dan fungsi organisasi dalam rangka memberikan keyakinan yang memadai bahwa kegiatan telah dilaksanakan sesuai dengan tolok ukur yang telah ditetapkan secara efektif dan efisien untuk kepentingan pimpinan dalam mewujudkan tata kelola/kepemerintahan yang baik.

Namun demikian, penugasan-penugasan pengawasan yang telah dilaksanakan oleh APIP sampai dengan saat ini, lebih dominan bersifat audit atas kejadian yang telah berlalu (post audit) yang berorientasi pada upaya pengungkapan temuan-temuan audit berupa penyimpangan efisiensi, efektivitas dan ketaatan terhadap ketentuan perundangan yang berlaku. Hasil pengawasan APIP sangat minim dalam memberikan informasi kepada pimpinan dalam upaya pencegahan dan pendeteksian tindak pidana korupsi. Keberadaan APIP pada instansi pemerintah, baik pusat maupun daerah belum mampu mencegah terjadinya tindak pidana korupsi.

\section{Identifikasi Faktor-Faktor Penyebab}

Dari hasil identifikasi ditinjau dari sisi peraturan perundang-undangan yang berlaku diantaranya Undang-Undang Nomor 23 Tahun 2014, Peraturan Pemerintah Republik Indonesia Nomor 60 Tahun 2008, Peraturan Pemerintah Republik Indonesia Nomor 18 Tahun 2016 Tentang Perangkat Daerah, Peraturan Pemerintah Republik Indonesia Nomor 12 Tahun 2017, Peraturan Presiden Nomor 4 Tahun 2015 Tentang Perubahan Keempat Atas Peraturan Presiden Nomor 54 Tahun 2010, dan Peraturan Menteri Dalam Negeri Nomor 64 Tahun 2007 diketahui terdapat beberapa faktor yang menyebabkan tidak maksimalnya Inspektorat Kabupaten/Kota dalam menjalankan kewenangan yang dimiliki untuk mencegah tindak pidana korupsi. Faktor-faktor tersebut adalah:

\section{Faktor Independensi dan Profesionalisme}

Berdasarkan Pasal 379 UU No. 23 Tahun 2014 tentang Pemerintahan Daerah, Inspektorat Kabupaten/Kota berkewajiban membantu Bupati/Walikota dalam membina 
dan mengawasi pelaksanaan Urusan Pemerintahan yang menjadi kewenangan Daerah dan Tugas Pembantuan oleh Perangkat Daerah. Berdasarkan struktur organisasi, inspektorat daerah berada di bawah dan bertanggung jawab langsung kepada kepala daerah dan secara administratif mendapat pembinaan dari sekretaris daerah. Dalam alur kerja, laporan hasil pengawasan inspektorat daerah ditujukan kepada kepala daerah (gubernur/bupati/walikota).

Sedangkan pada Pasal 16 Peraturan Pemerintah Republik Indonesia Nomor 12 Tahun 2017 disebutkan bahwa sebagai salah satu bagian dari Aparat Pengawas Internal Pemerintah (APIP), Inspektorat Kabupaten/Kota juga dituntut dalam menjalankan prinsip pembinaan dan pengawasan harus dilaksanakan berdasarkan prinsip profesional; independen; objektif; tidak tumpang tindih antar-APIP; dan berorientasi pada perbaikan dan peringatan dini. Praktik ini di lapangan dinilai mengurangi independensi dan objektivitas inspektorat daerah dalam menjalankan tugasnya.

Dari penjelasan pasal 16 pada Peraturan Pemerintah Republik Indonesia Nomor 12 Tahun 2017 ada 3 prinsip yang berpotensi besar berbenturan dengan kewenangan yang dimiliki oleh Inspektorat Kabupaten/Kota. Ketiganya adalah prinsip profesional, independen dan objektif. Yang dimaksud dengan "profesional" adalah pekerjaan atau kegiatan yang dilakukan oleh seseorang dan menjadi sumber penghasilan kehidupan yang memerlukan keahlian, kemahiran, atau kecakapan yang memenuhi standar mutu atau norma tertentu serta memerlukan pendidikan profesi. Selanjutnya yang dimaksud dengan "independen" adalah sikap tidak memihak serta tidak dibawah pengaruh atau tekanan pihak tertentu dalam mengambil keputusan dan tindakan dalam melaksanakan pengawasan. Sedangkan yang dimaksud dengan "objektif" adalah memiliki sikap yang netral dan tidak bias serta menghindari konflik kepentingan dalam merencanakan, melaksanakan, dan melaporkan pekerjaan yang dilakukannya.

Selain kedua peraturan tersebut, faktor independensi Inspektorat Kabupaten/Kota juga dapat dilihat pada Peraturan Pemerintah Nomor: 60 Tahun 2008 tentang SPIP. Sistem Pengendalian Intern Pemerintah (SPIP) adalah sistem pengendalian intern yang diselenggarakan secara menyeluruh di lingkungan Pemerintah Pusat dan pemda. Peraturan Pemerintah Nomor: 60 Tahun 2008 tentang SPIP mewajibkan menteri/pimpinan lembaga, gubernur, dan bupati/wali kota untuk mengendalikan penyelenggaraan pemerintahan.

Kebijakan tersebut juga senada dengan pengaturan dalam UU No. 23 Tahun 2014 tentang Pemerintahan Daerah yang mendudukkan Inspektorat di bawah sekretaris daerah. Kedudukan ini menempatkan Inspektorat bukan pada posisi yang bisa melakukan pengendalian dan pengawasan dengan maksimal.

\section{Faktor Kompetensi Inspektorat Kabupaten/Kota}

Faktor penyebab kedua adalah profesionalisme dan kompetensi Inspektorat Kabupaten/Kota yang belum sepenuhnya terbentuk. Sebagian besar Inspektorat Kabupaten/Kota masih belum memiliki kompetensi minimum yang dipersyaratkan. Kompetensi untuk melakukan fungsi pengawasan internal pemerintah paling tidak dibuktikan dengan kemampuan melakukan audit, review, evaluasi, investigasi dan lainlain. Secara formal para pengawas ini harus memiliki kompetensi dalam jabatan fungsional auditor yang tersertifikasi atau setidaknya terstandardisasi (certified auditor). 
Hal ini sebenarnya telah diatur pada Peraturan Pemerintah Republik Indonesia Nomor 12 Tahun 2017 tentang Pembinaan dan Pengawasan Penyelenggaraan Pemerintahan Daerah. Sebagaimana sudah dijelaskan di pasal 16 bahwa Pengawasan Penyelenggaraan Pemerintahan Daerah yang dilaksanakan oleh APIP harus berdasarkan kompetensi yang dimiliki terkait dengan pelaksanaan pengawasan urusan pemerintahan yang menjadi kewenangan daerah sesuai fungsi dan kewenangannya serta sesuai dengan ketentuan peraturan perundang-undangan (Angka 1).

\section{MODIFIKASI HUKUM KEWENANGAN INSPEKTORAT KABUPATEN/KOTA DALAM MENCEGAH TERJADINYA TINDAK PIDANA KORUPSI DI PEMERINTAH DAERAH KABUPATEN/KOTA.}

1. Modifikasi Hukum Kewenangan Inspektorat Kabupaten/Kota yang mengacu kepada perundang-undangan

Dengan berpedoman pada evaluating analysis yang telah dilakukan terhadap peraturan perundang-undangan yang terkait dengan kewenangan Inspektorat Kabupaten/Kota, yang perlu dimodifikasi adalah pengaturan-pengaturan yang terdapat dalam UU Nomor 23 Tahun 2014 tentang Pemerintahan Daerah, Peraturan Pemerintah Republik Indonesia Nomor 60 Tahun 2008 tentang Sistem Pengendalian Intern Pemerintah, Peraturan Pemerintah Republik Indonesia Nomor 18 Tahun 2016 Tentang Perangkat Daerah, Peraturan Pemerintah Republik Indonesia Nomor 12 Tahun 2017 tentang Pembinaan Dan Pengawasan Penyelenggaraan Pemerintahan Daerah, Peraturan Menteri Dalam Negeri Nomor 64 Tahun 2007 tentang Pedoman Teknis Organisasi Dan Tata Kerja Inspektorat Provinsi Dan Kabupaten/Kota, dan Peraturan Walikota Batu Nomor 70 Tahun 2016 Tentang Kedudukan, Susunan Organisasi, Uraian Tugas Dan Fungsi, Serta Tata Kerja Inspektorat Kota Batu. Walaupun tidak berhubungan langsung dan tidak termasuk yang dievaluasi di atas, UU No. 5 Tahun 2014 tentang Aparatur Sipil Negara masuk dalam klasifikasi yang perlu dimodifikasi.

Modifikasi hukum yang dapat dilakukan adalah melakukan perubahan/revisi terhadap isi pasal dalam Undang-Undang Nomor 23 Tahun 2014 tentang Pemerintahan Daerah khususnya pada pasal 216 yang mengatur tentang kedudukan Inspektorat Kabupaten/Kota dan melakukan perubahan/revisi terhadap Peraturan Pemerintah Republik Indonesia Nomor 18 Tahun 2016 Tentang Perangkat Daerah dikarenakan terdapat benturan dengan peraturan yang terdapat dalam Peraturan Pemerintah Republik Indonesia Nomor 12 Tahun 2017 tentang Pembinaan Dan Pengawasan Penyelenggaraan Pemerintahan Daerah khususnya di pasal 16. Benturan sebagaimana dimaksud terletak pada kedudukan Inspektorat Kabupaten/Kota yang berada di bawah Sekretaris Daerah, sedangkan pada aturan di bawahnya dituntut untuk profesional, independen dan objektif. Untuk dapat melaksanakan tugasnya secara profesional, independen dan objektif, perubahan yang dapat dilakukan adalah dengan merubah/mereposisi kedudukan Inspektorat Kabupaten/Kota.

Alternatif perubahan yang dapat dilakukan adalah dengan mengadopsi kedudukan Internal Auditor di dalam struktur organisasi suatu perusahaan. Secara garis besar ada tiga alternatif posisi atau kedudukan dari Internal Auditor dalam struktur organisasi perusahaan sebagaimana gambar berikut : 


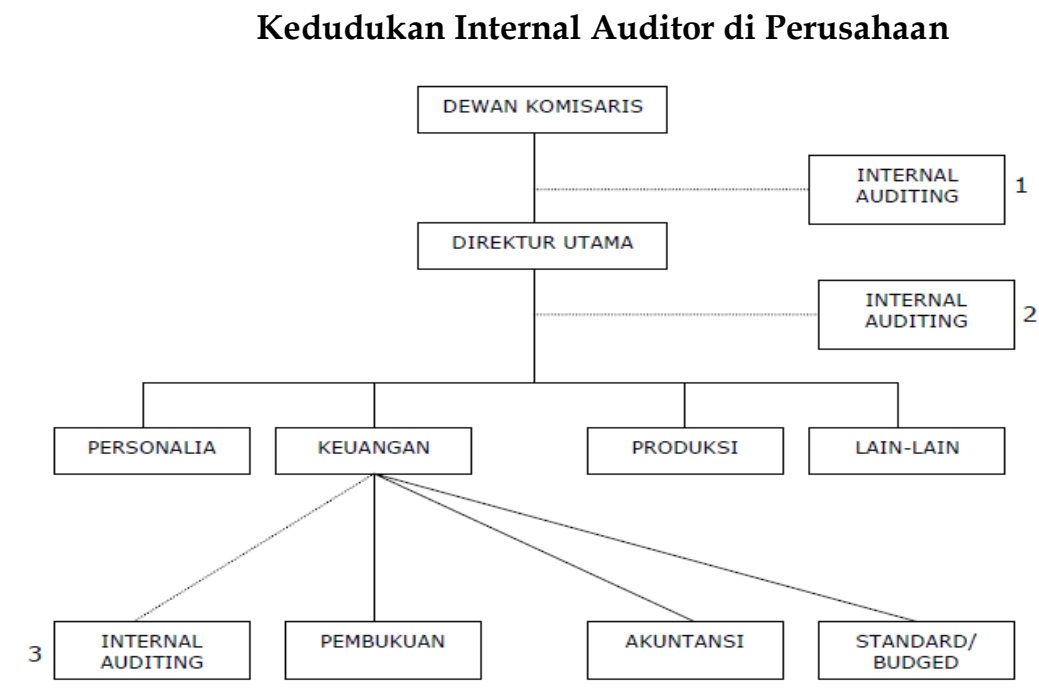

\section{Keterangan :}

Dalam gambar di atas dapat dilihat mengenai posisi atau kedudukan intern auditing.

1. Internal Auditing berada di bawah Dewan Komisaris

2. Internal Auditing berada di bawah Direktur Utama

3. Internal Auditing berada di bawah Kepala Bagian Keuangan

Apabila struktur kedudukan Internal auditor di perusahaan tersebut diaplikasikan dalam kedudukan Inspektorat Kabupaten/Kota, ada 2 alternatif kedudukan Inspektorat Kabupaten/Kota yang mungkin yaitu berada dibawah Presiden melalui Gubernur, dan berada dibawah Bupati/Walikota sebagaimana gambar berikut :

Alternatif Kedudukan Inspektorat Kabupaten/Kota Setelah Modifikasi

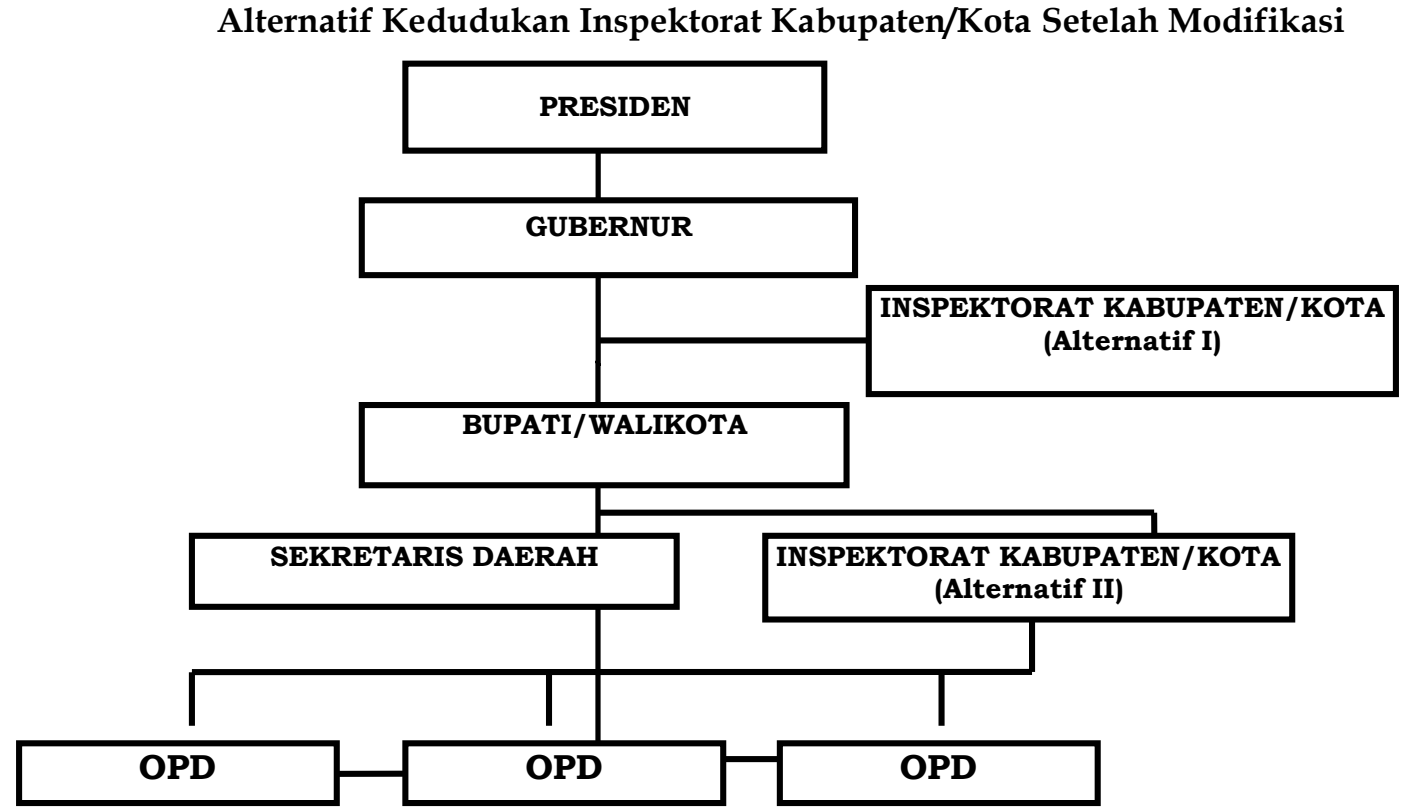

Dari dua (2) alternatif perubahan kedudukan Inspektorat Kabupaten/Kota, yang paling mungkin dilakukan saat ini adalah merubah kedudukan Inspektorat Kabupaten/Kota menjadi sejajar dengan kedudukan Sekretaris Daerah. Dengan kedudukan yang setara Sekretaris Daerah, diharapkan ke depan Inspektorat dapat lebih memiliki wibawa dan independen dalam melakukan pengawasan terhadap Pemerintah Daerah. 


\section{Modifikasi Kedudukan Inspektorat Kabupaten/Kota dalam mencegah terjadinya tindak pidana korupsi di Pemerintah Daerah Kabupaten/Kota}

Keberadaan Inspektorat Kabupaten/Kota sebagai bagian auditor intern pemerintah yang independen dalam jajaran organisasi pemerintahan diyakini akan memberikan nilai tambah terhadap seluruh stakeholders. Seluruh upaya yang diperankan Inspektorat Kabupaten/Kota merupakan dorongan bagi diterapkannya good governance pada setiap jenjang pemerintahan serta pengelola investasi kekayaan negara yang dipisahkan. Selain itu, Inspektorat Kabupaten/Kota merupakan kekuatan pendorong dalam upaya peningkatan efektifitas, efisiensi, serta kehematan penyelenggaraan pelayanan publik dan pembangunan nasional. Hal ini akan meningkatkan kepercayaan masyarakat dalam dan luar negeri terhadap kredibilitas pemerintah dalam upaya mewujudkan masyarakat madani. Pada akhirnya akan bermuara kepada terwujudnya kesejahteraan masyarakat dan mencerdaskan kehidupan bangsa sebagaimana diamanatkan di dalam Pembukaan Undang-undang Dasar 1945.

\section{a. Reposisi Peran/Tugas Inspektorat Kabupaten/Kota}

Dengan memperhatikan ekspektasi stakeholder, lingkungan eksternal/internal dan memperhatikan organization capability, keberadaan auditor intern pemerintah perlu direposisi dan mengambil peran menjadi: Auditor Intern Pemerintah yang Profesional dalam mendukung upaya Pemerintah mewujudkan Good Governance dan Clean Government.

Peran Inspektorat Kabupaten/Kota sebagai auditor intern pemerintah sebagaimana diuraikan di atas dapat diwujudkan dalam bentuk:

a. Mendorong terwujudnya Good Governance dan Clean Government

b. Menumbuhkembangkan Sinergi Pengawasan

c. Mendukung Upaya Pemberantasan KKN

d. Mengoptimalkan Peningkatan Penerimaan Negara

e. Berperan dalam Pelaksanaan Otonomi Daerah

b. Pengembangan Kelembagaan

\section{Pengembangan Struktur}

Nilai ekonomis informasi hasil audit adalah fungsi dari kompetensi menemukan kemungkinan penyimpangan dan independensi untuk melaporkannya. Jadi, konstelasi keberadaan Inspektorat Kabupaten/Kota perlu didayagunakan untuk mewujudkan pengawasan yang efisien dan efektif dalam rangka menuju good governance. Bila Inspektorat Kabupaten/Kota mengidentifikasikan dirinya selaku unit yang melakukan pekerjaan utamanya dengan memproduksi dan menyerahkan jasa kepada user, maka mekanisme koordinasi yang cocok dan tepat dengan situasi tersebut dapat dipilih.

\section{Pengembangan Prosedur Kerja}

Mengingat keberadaan Inspektorat Kabupaten/Kota sebagai salah satu Aparat Pengawas Internal Pemerintah (APIP) pada berbagai sektor dan tingkatan pemerintahan, prosedur kerja baku perlu dikembangkan sebagai acuan untuk proses interaksi dalam rangka mensinergikan gerak dan langkah pengawasan dalam tataran yang bersifat makro agregat. Pada intinya, prosedur kerja tersebut dimaksudkan untuk menginternalisasikan keseluruhan mekanisme koordinasi yang akan digunakan. Artinya, akan diperlukan prosedur kerja untuk 'mengelola' rules yang ditetapkan, 'merancang, menetapkan dan 
melaksanakan' work program yang ditetapkan, 'mengembangkan' standardisasi faktor input, proses maupun output, 'melaporkan' hasil pengawasan, serta 'memantau' pelaksanaan hasil pengawasan. Untuk itu, penggunaan teknologi informasi dan komunikasi akan sangat mendukung proses koordinasi APIP. Disadari atau tidak, perkembangan sistem dan teknologi informasi merupakan tantangan sekaligus peluang bagi APIP dalam rangka mendukung tugas-tugas strategis pemerintah di bidang pengawasan.

Secara konkret, pemanfaatan teknologi informasi dan komunikasi dilakukan dengan menerapkan platform system dan teknologi yang secara teknis mampu berkolaborasi, saling mendukung dan kompatibel. Artinya, seluruh jajaran APIP diupayakan untuk dapat memfasilitasi dirinya dengan sistem aplikasi berikut dukungan teknologinya yang dapat membantu tugas-tugas operasional di bidang pengawasan.

\section{Pengembangan Sumber Daya Manusia}

Sumber daya manusia adalah unsur yang paling vital dalam fungsi pengawasan intern berhubung manusialah yang merancang, merencanakan, dan melakukan seluruh tugas pengawasaan. Dengan konstelasi aparatur pengawasan intern pemerintah yang disertai dengan kompleksitas dan keberagaman tugas pengawasan, standardisasi keahlian dan pengetahuan sebagai faktor input merupakan aspek kunci agar pengawasan dapat berjalan secara efektif dan efisien. Pilihan mekanisme koordinasi dalam bentuk standardisasi ini tentu harus disertai dengan proses pendidikan dan pelatihan, serta indoktrinasi terhadap hal-hal yang berkaitan dengan perilaku pelaksana tugas pengawasan.

Dalam bahasa profesi pengawasan, keahlian dan pengetahuan untuk melaksanakan tugas pengawasan diwujudkan dalam penerapan standar audit dan kode etik. Standar audit dan kode etik sebenarnya mengandung unsur-unsur universal. Universalitas ini merupakan konsekuensi dari persepsi bahwa mutu audit memang tidak memandang di mana dan oleh siapa audit tersebut dilakukan. Sepanjang seseorang berprofesi sebagai auditor intern maka ia akan dituntut untuk melakukan audit dalam kualitas yang berlaku umum seperti independen, objektif, dan cermat.

Oleh karena itu, penyusunan standar audit internal tidak bergantung pada kewenangan. Ia lebih bergantung pada seberapa tinggi mutu yang akan ditetapkan untuk dicapai. Dengan memperhatikan universalitas ukuran mutu ini maka sebenarnya dunia auditor intern pemerintah dapat mengadopsi standar dan kode etik auditor intern pada umumnya.

\section{PENUTUP}

Kewenangan yang dimiliki Inspektorat Daerah Kabupaten/Kota diatur dalam beberapa peraturan perundang-undangan yaitu :

a. Undang-Undang Nomor 23 Tahun 2014 tentang Pemerintahan Daerah

b. Peraturan Pemerintah Republik Indonesia Nomor 60 Tahun 2008 tentang Sistem Pengendalian Internal Pemerintah

c. Peraturan Pemerintah Republik Indonesia Nomor 18 Tahun 2016 Tentang Perangkat Daerah 
d. Peraturan Pemerintah Republik Indonesia Nomor 12 Tahun 2017 tentang Pembinaan Dan Pengawasan Penyelenggaraan Pemerintahan Daerah

e. Peraturan Presiden Nomor 54 Tahun 2010 tentang Pengadaan Barang/Jasa Pemerintah

f. Peraturan Menteri Dalam Negeri Nomor 64 Tahun 2007 tentang Pedoman Teknis Organisasi Dan Tata Kerja Inspektorat Provinsi Dan Kabupaten/Kota

Kewenangan Inspektorat Daerah Kabupaten/Kota adalah membina dan mengawasi pelaksanaan Urusan Pemerintahan yang menjadi kewenangan Daerah dan Tugas Pembantuan oleh Perangkat Daerah. Kewenangan pengawasan berdasarkan peraturan perundang-undangan bersifat pasif dan abstrak, dan untuk membuat kewenangan tersebut menjadi aktif dan konkret maka diadakan sebuah program kerja pengawasan yang berbasis pada kewenangan secara positivis khususnya dalam mencegah terjadinya tindak pidana korupsi.

Faktor-faktor yang menyebabkan tidak maksimalnya Inspektorat Daerah Kabupaten/Kota dalam menjalankan kewenangan yang dimiliki untuk mencegah tindak pidana korupsi adalah :

a. Faktor Independensi dan Profesionalisme

b. Faktor Kompetensi Inspektorat Daerah Kabupaten/Kota

c. Belum Tegas Dan Jelasnya Pembagian Fungsi Pengawasan Internal dan Eksternal

Modifikasi Hukum Kewenangan Inspektorat Daerah Kabupaten/Kota dalam mencegah terjadinya tindak pidana korupsi di Pemerintah Daerah Kabupaten/Kota dapat dilakukan dengan beberapa alternatif sebagai berikut :

a. Modifikasi Hukum Kewenangan Inspektorat Daerah Kabupaten/Kota yang mengacu kepada peraturan perundang-undangan dengan jalan melakukan perubahan/revisi terhadap isi pasal dalam Undang-Undang Nomor 23 Tahun 2014 tentang Pemerintahan Daerah khususnya pada pasal 216 yang mengatur tentang kedudukan Inspektorat Daerah Kabupaten/Kota dan melakukan perubahan/revisi terhadap Peraturan Pemerintah Republik Indonesia Nomor 18 Tahun 2016 Tentang Perangkat Daerah. Adapun modifikasi kedudukan Inspektorat Daerah Kabupaten/Kota yang paling memungkinkan untuk saat ini adalah sejajar dengan Sekretaris Daerah.

b. Reposisi Peran/Tugas Inspektorat Daerah Kabupaten/Kota dalam bentuk mendorong terwujudnya good governance dan clean government, menumbuhkembangkan sinergi pengawasan, mendukung upaya pemberantasan KKN, mengoptimalkan peningkatan penerimaan negara, berperan dalam pelaksanaan otonomi daerah.

c. Pengembangan Kelembagaan melalui pengembangan struktur, Prosedur Kerja, dan Sumber Daya Manusia.

Peraturan Perundang-undangan yang mengatur tentang Kewenangan Inspektorat Daerah Kabupaten/Kota mendesak untuk direvisi untuk dapat meningkatkan peran Inspektorat Daerah Kabupaten/Kota dalam mencegah terjadinya tindak pidana korupsi di Pemerintah Kabupaten/Kota. Sinergi dalam hal pengawasan dengan Aparat Pengawas Internal Pemerintah lainnya serta Aparat Pengawas Eksternal dan Aparat Penegak Hukum juga perlu ditingkatkan sebagai salah satu upaya mencegah terjadinya tindak pidana korupsi. Pengembangan kapasitas sumber daya manusia di Internal Inspektorat Daerah Kabupaten/Kota perlu untuk ditingkatkan. 


\section{DAFTAR PUSTAKA}

Buku:

Anwar, Saiful, Sendi-Sendi Hukum Administrasi Negara, Jakarta: Glora Madani Press, 2004.

Budiardjo, Miriam, Dasar-Dasar Ilmu Politik, Jakarta: Gramedia Pustaka Utama, 1998.

Hidjaz, Kamal, Efektivitas Penyelenggaraan Kewenangan Dalam Sistem Pemerintahan Daerah di Indonesia, Makasar: Pustaka Refleksi.

HR, Ridwan, HukumAdministrasi Negara, Jakarta: Raja Grafindo Persada, 2008.

Ibrahim, Johnny, Teori \& Metodologi Penelitian Hukum Normatif, Malang : Bayumedia, 2008.

Kelsen, Hans, Teori Umum Tentang Hukum dan Negara (diterjemahkan oleh Raisul Muttaqien dari Hans Kelsen, 1971, General Theory of Law and State, Russel and Russel, New York), Bandung: Nusamedia dan Nuansa, 2006.

Lailam, Tanto, Pengantar Ilmu Hukum Administrasi Negara, Yogyakarta: Prudent Media, 2012.

M. Hadjon, Philipus, Tentang Wewenang Pemerintahan (Bestuurbevoegdheid), Pro Justitia Tahun XVI Nomor I Januari 1998, 1998.

Mahfud MD, Moh., Membangun Politik Hukum, Menegakkan Konstitusi, Jakarta: LP3ES, 2006.

Marzuki, Peter Mahmud, Penelitian Hukum. Jakarta: Kencana - Prenada Media Group, 2005.

Muchsan, Sistem Pengawasan Terhadap Perbuatan Aparat Pemerintah dan Peradilan Tata Usaha Negara Indonesia, Yogyakarta: Liberty, 1992.

Mudhofir, Ali, Kamus Teori dan Aliran dalam Filsafat dan Teologi, Yogyakarta: Gajahmada University Press, 1996.

Muhammad, Abdulkadir, Hukum dan Penelitian Hukum, Bandung: PT. Citra Aditya Bakti, 2004.

Prayudi, Hukum Administrasi Negara, Jakarta: Ghalia Indonesia, 1981.

Ridwan, Juniarso dan Achmad Sodik Sudrajat, Hukum Administrasi Negara dan Kebijakan Pelayanan Publik, Jakarta: Nuansa, 2012.

Sadjijono, Memahami Beberapa Bab Pokok Hukum Administrasi, Yogyakarta: LaksBang Pressindo, 2008.

Semma, Mansyur, Negara dan Korupsi Pemikiran Mochtar Lubis atas Negara, Manusia Indonesia, dan Perilaku Politik. Jakarta: Buku Obor, 2008.

Soekanto, Soerjono, Pengantar Penelitian Hukum (Cetakan Ketiga), Jakarta: UI-PRESS, 1986.

Sujanto, Beberapa Pengertian di Bidang Pengawasan, Jakarta: Ghalia Indonesia, 1986.

Tanya, Bernard L., Teori Hukum: Strategi Tertib Manusia Lintas Ruang dan Generasi, Yogyakarta, 2010.

Tim Penulis Buku Pendidikan Anti Korupsi, Pendidikan Anti Korupsi untuk Perguruan Tinggi/Anti Korupsi, Jakarta: Kemendikbud, 2011.

Tim Penyusun Kamus Pusat Bahasa, Kamus Besar Bahasa Indonesia, Edisi III, Cet. I. Jakarta: Balai Pustaka, 2001.

Wakhyudi, Ak., M.B.A,. Filosofi Auditing. Jakarta: Pusat Pendidikan dan Pelatihan Pengawasan BPKP, 2007.

Makalah, Artikel, Jurnal dan Hasil Penelitian:

Ardiansyah. 2014, Fokus Kajian Teori Kewenangan.

Indroharto. 1994. Asas-Asas Umum Pemerintahan yang Baik, dalam Paulus Efendie Lotulung. Bandung: Himpunan Makalah Asas-Asas Umum Pemerintahan yang Baik, Citra Aditya Bakti. 
Kantaprawira, Rusadi. 1998. Hukum dan Kekuasaan. Yogyakarta: Makalah, Universitas Islam Indonesia

Lapananda, Yusran. 2014. Pengembalian Kerugian Negara/Daerah, Unsur Merugikan Keuangan Negara Dan Tindak Pidana Korupsi.

Pungus, Sonny. 2011. Teori Kewenangan.

Purba, Robiharto. 2014. Makalah Tentang Demokrasi Di Indonesia. Palangkaraya.

Putra, Handriyas. 2011. Pelaksanaan Fungsi Pengawasan Fungsional Di Inspektorat Kota Solok.

Rampengan, Margareth Carla. 2013. Fungsi Laporan Hasil Pemeriksaan (LHP) Badan Pemeriksa Keuangan Dalam Kasus Tindak Pidana Korupsi. dimuat dalam Lex Crimen Vol. II/No. 2/ Apr-Jun/2013.

Suhartanto. Strategi Pencegahan Tindak Pidana Korupsi: Mengoptimalkan Peran Aparat Pengawasan Internal Dalam Upaya Pencegahan Tindak Pidana Korupsi.

Suryanto, Agus. Studi Keterlambatan Tindak Lanjut Temuan Hasil Pemeriksaan Inspektorat Daerah Kabupaten Kulonprogo D.I Yogyakarta Dan Implementasi Manajerial.

Syafrudin, Ateng. 2000. Menuju Penyelenggaraan Pemerintahan Negara yang Bersih dan Bertanggung Jawab. Jurnal Pro Justisia Edisi IV. Bandung : Universitas Parahyangan

Tamaka, Arther Nus. 2014. Kinerja Inspektorat Daerah Dalam Melakukan Fungsi Pengawasan.

Waseso, Budi. 2015. Pemanfaatan Informasi Hasil Audit Apip dalam Penanganan Perkara Korupsi. Jakarta.

Yosa. 2010. Pengawasan sebagai Sarana Penegakan Hukum Administrasi Negara. Jurnal Depdagri.

Peraturan Perundang-Undangan:

Undang-Undang Nomor 31 Tahun 1999 jo Undang-Undang Nomor 20 Tahun 2001 tentang Pemberantasan Tindak Pidana Korupsi.

Undang-Undang Nomor 23 Tahun 2014 tentang Pemerintahan Daerah

Undang-Undang Republik Indonesia Nomor 30 Tahun 2014 tentang Administrasi Pemerintahan.

Peraturan Pemerintah Republik Indonesia Nomor 60 Tahun 2008 tentang Sistem Pengendalian Internal Pemerintah

Peraturan Pemerintah Republik Indonesia Nomor 18 Tahun 2016 tentang Perangkat Daerah.

Peraturan Pemerintah Republik Indonesia Nomor 12 Tahun 2017 tentang Pembinaan Dan Pengawasan Penyelenggaraan Pemerintahan Daerah.

Peraturan Presiden Nomor 54 Tahun 2010 tentang Pengadaan Barang/Jasa Pemerintah.

Peraturan Menteri Dalam Negeri Nomor 64 Tahun 2007 tentang Pedoman Teknis Organisasi Dan Tata Kerja Inspektorat Provinsi Dan Kabupaten/Kota.

Peraturan Menteri Negara Pendayagunaan Aparatur Negara Nomor : Per/05/M.Pan/03/2008 tentang Standar Audit Aparat Pengawasan Intern Pemerintah.

Peraturan Menteri Dalam Negeri Nomor 8 Tahun 2009 tentang Perubahan Atas Peraturan Menteri Dalam Negeri Nomor 23 Tahun 2007 tentang Pedoman Tata Cara Pengawasan Atas Penyelenggaraan Pemerintahan Daerah.

Peraturan Menteri Negara Pendayagunaan Aparatur Negara Nomor 9 Tahun 2009 tentang Pedoman Umum Pelaksanaan, Pemantauan, Evaluasi, dan Pelaporan Tindak Lanjut Hasil Pengawasan Fungsional.

Peraturan Menteri Negara Pendayagunaan Aparatur Negara Nomor 19 Tahun 2009 tentang Pedoman Kendali Mutu Audit Aparat Pengawasan Intern Pemerintah. 